\title{
Paenibacillus xylanilyticus sp. nov., an airborne xylanolytic bacterium
}

Correspondence

Encarna Velázquez

evp@gugu.usal.es

\author{
Raúl Rivas, Pedro F. Mateos, Eustoquio Martínez-Molina \\ and Encarna Velázquez
}

Departamento de Microbiología y Genética, Lab. 209, Edificio Departamental de Biología, Universidad de Salamanca, Campus M. Unamuno, 37007 Salamanca, Spain

\begin{abstract}
During a search for xylan-degrading micro-organisms, a sporulating bacterium was recovered from xylan-containing agar plates exposed to air in a research laboratory (Salamanca University, Spain). The airborne isolate (designated strain XIL14 $4^{\top}$ ) was identified by $16 \mathrm{~S}$ rRNA gene sequencing as representing a Paenibacillus species most closely related to Paenibacillus illinoisensis JCM $9907^{\top}$ (99.3\% sequence similarity) and Paenibacillus pabuli DSM $3036^{\top}$ (98\% sequence similarity). Phenotypic, chemotaxonomic and DNA-DNA hybridization data indicated that the isolate belongs to a novel species of the genus Paenibacillus. Cells of strain XIL $14^{\top}$ were motile, sporulating, rod-shaped, Gram-positive and facultatively anaerobic. The predominant cellular fatty acids were anteiso- $\mathrm{C}_{15: 0}$ and $\mathrm{C}_{16: 0}$. The DNA $\mathrm{G}+\mathrm{C}$ content of strain XIL14 ${ }^{\top}$ was 50.5 mol\%. Growth was observed with many carbohydrates, including xylan, as the only carbon source and gas production was not observed from glucose. Catalase was positive and oxidase was negative. The airborne isolate produced a variety of hydrolytic enzymes, including xylanases, amylases, gelatinase and $\beta$-galactosidase. DNA-DNA hybridization levels between strain XIL14 ${ }^{\top}$ and $P$. illinoisensis DSM $11733^{\top}$ and P. pabuli DSM $3036^{\top}$ were $43 \cdot 3$ and $36 \cdot 3 \%$, respectively. According to the data obtained, strain $\mathrm{XIL1} 14^{\top}$ is considered to represent a novel species for which the name Paenibacillus xylanilyticus sp. nov. is proposed (=LMG $21957^{\top}=$ CECT $5839^{\top}$ ).
\end{abstract}

Xylan is a heterogeneous polymer composed of $(1,4)$-linked $\beta$-D-xylosyl residues. It is very abundant in nature, being the major component of hemicelluloses of monocotyledon cell walls. Xylanases (1,4- $\beta$-D-xylanohydrolase) are a group of xylanolytic enzymes that hydrolyse xylan to xylanoligosaccharides and xylose. The genus Paenibacillus, which was originally proposed by Ash et al. (1993) (valid publication by Ash et al., 1994), contains some species that are able to hydrolyse xylan (Ay et al., 1998; Hespell, 1996; Lee et al., 2000; Morales et al., 1995; Nielsen \& Sorensen, 1997; Zamost et al., 1991). Recently, a novel xylanolytic Paenibacillus species, Paenibacillus favisporus, was described (Velázquez et al., 2004).

Within the framework of a screening programme to search for xylan-degrading micro-organisms, we isolated a bacterial strain $\left(\mathrm{XIL}_{14}{ }^{\mathrm{T}}\right)$ that actively hydrolysed xylan. Isolation was made in YNBX medium containing xylan as single source of carbon, as previously described (Velázquez et al.,

The GenBank/EMBL/DDBJ accession number for the $16 \mathrm{~S}$ rRNA gene sequence of XIL14 ${ }^{\top}$ is $A Y 427832$.

An extended phylogenetic tree of representative Paenibacillus strains is available as a supplementary figure in IJSEM Online.
2004). Colonies of the airborne bacterium were cream coloured, opaque, rounded and convex.

Strain XIL14 ${ }^{\mathrm{T}}$ was grown for $48 \mathrm{~h}$ and motility was checked under a scanning electron microscope. Gram behaviour of the cells was ascertained by staining (Doetsch, 1981). Cells of strain XIL14 ${ }^{\mathrm{T}}$ were Gram-positive, rod-shaped, sporulating and motile (peritrichous flagellation).

Amplification and sequencing of the 16S rRNA gene were performed as described by Rivas et al. (2003a). The sequence obtained was compared with those from GenBank using the FASTA program (Pearson \& Lipman, 1988). Sequences were aligned using the CLUSTAL $\mathrm{W}$ software (Thompson et al., 1997). Distances were calculated by using the method of Kimura (1980). Phylogenetic trees were inferred using the neighbour-joining method (Saitou \& Nei, 1987). The MEGA 2.1.0 package (Kumar et al., 2001) was used for all analyses.

The complete (1546 bp) 16S rRNA gene sequence of strain XIL14 ${ }^{\mathrm{T}}$ was determined. A comparison against the 16S rRNA gene sequences held in the GenBank database indicated that strain $\mathrm{XIL}^{\mathrm{T}}{ }^{\mathrm{T}}$ is phylogenetically related to strains and species of the genus Paenibacillus. 16S rRNA 


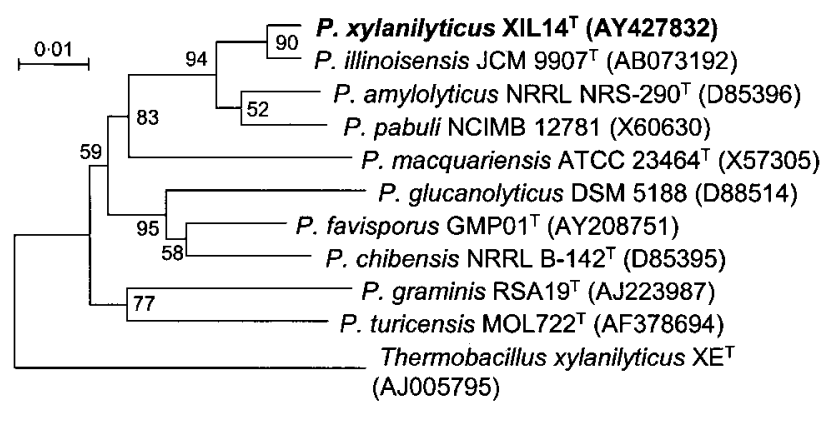

Fig. 1. Comparative analysis of the $16 \mathrm{~S}$ rRNA gene sequences of Paenibacillus xylanilyticus sp. nov. and representative strains from GenBank using the neighbour-joining method. The analysis was based on $1411 \mathrm{nt}$. The significance of each branch is indicated by a bootstrap percentage calculated for 1000 subsets. Bar, 1 substitution per $100 \mathrm{nt}$. An extended tree containing a wider selection of reference sequences is available in IJSEM Online.

gene sequence similarities to all other recognized Paenibacillus species ranged from $89 \cdot 8 \%$ with Paenibacillus alginolyticus to $99 \cdot 3 \%$ with Paenibacillus illinoisensis. Fig. 1 shows the phylogenetic tree obtained with the neighbourjoining method (a more complete phylogenetic tree is available as a supplementary figure in IJSEM Online). The closest related recognized species are $P$. illinoisensis JCM $9907^{\mathrm{T}}\left(=\mathrm{DSM} 11733^{\mathrm{T}}\right.$ ) with $99 \cdot 3 \%$ similarity and Paenibacillus pabuli DSM $3036^{\mathrm{T}}$ with $98 \cdot 4 \%$ similarity.

For base composition analysis, DNA was prepared according to the method of Chun \& Goodfellow (1995), and the $\mathrm{G}+\mathrm{C}$ content was determined using the thermal denaturation method (Mandel \& Marmur, 1968). The DNA G +C content of strain XIL14 ${ }^{\mathrm{T}}$ was $50 \cdot 5 \mathrm{~mol} \%$.

For DNA-DNA hybridization analyses, DNA was isolated by chromatography on hydroxyapatite by the procedure of Cashion et al. (1977), which was carried out as described by De Ley et al. (1970) but using the modifications described by Huß et al. (1983) and Escara \& Hutton (1980). Renaturation rates were determined with the TRANSFER.BAS program (Jahnke, 1992). DNA-DNA relatedness was tested [in $2 \times \mathrm{SSC}+10 \%(\mathrm{v} / \mathrm{v}) \mathrm{DMSO}$ at $68^{\circ} \mathrm{C}$ ] among strains XIL14 ${ }^{\mathrm{T}}, P$. illinoisensis DSM $11733^{\mathrm{T}}$ and P. pabuli DSM $3036^{\mathrm{T}}$. Levels of DNA-DNA relatedness between strain XIL14 ${ }^{\mathrm{T}}$ and P. illinoisensis DSM $11733^{\mathrm{T}}$ and P. pabuli DSM $3036^{\mathrm{T}}$ were $43 \cdot 3$ and $36 \cdot 3 \%$, respectively. These results indicate that strain XIL14 ${ }^{\mathrm{T}}$ is not a representative of either of these species, using the recommended threshold value of $70 \%$ DNA-DNA relatedness for the definition of genomic species (Wayne et al., 1987).

The predominant fatty acids analysed by GLC as described by Rivas et al. (2003b) were anteiso- $\mathrm{C}_{15: 0}$ and $\mathrm{C}_{16: 0}$, respectively comprising 47.9 and $16.6 \%$ of the total. These values coincide with those reported for $P$. illinoisensis and P. pabuli (Shida et al., 1997a, b) (Table 2). Other fatty acids
Table 1. Distinguishing phenotypic characteristics of the species phylogenetically related to Paenibacillus xylanilyticus sp. nov.

Strains: 1, P. xylanilyticus sp. nov. XIL14 ${ }^{\mathrm{T}} ; 2$, P. illinoisensis NRRL NRS- $1356^{\mathrm{T}}$; 3, P. pabuli NRRL NRS- $924^{\mathrm{T}}$; 4, P. amylolyticus NRRL NRS $-290^{\mathrm{T}}$. Data for reference strains are from Meehan et al. (2001) and Velázquez et al. (2004). +, Positive; -, negative; $\mathrm{V}$, variable; ND, no data. All species grow anaerobically and are positive for catalase, production of amylases and acid production from L-arabinose, mannitol and D-xylose. All species are negative for oxidase and production of tyrosinase and citrate.

\begin{tabular}{|lcccc|}
\hline Test & $\mathbf{1}$ & $\mathbf{2}$ & $\mathbf{3}$ & $\mathbf{4}$ \\
\hline Optimum growth temperature $\left({ }^{\circ} \mathrm{C}\right)$ & 37 & 37 & $28-30$ & $28-30$ \\
Nitrate reduction & - & - & - & + \\
Production of: & & & & \\
$\quad$ Acetylmethylcarbinol & + & - & - & - \\
Indole & - & $\mathrm{ND}$ & - & - \\
Dihydroxyacetone & - & $\mathrm{ND}$ & $\mathrm{ND}$ & $\mathrm{ND}$ \\
pH in MR-VP broth & $<4$ & $5 \cdot 0-5 \cdot 2$ & $<5 \cdot 5$ & $<5 \cdot 5$ \\
Caseinase & - & + & $\mathrm{V}$ & - \\
Growth at pH $5 \cdot 6$ & - & + & + & + \\
Growth at $50^{\circ} \mathrm{C}$ & - & + & - & - \\
Growth in the presence of $5 \% \mathrm{NaCl}$ & + & - & $\mathrm{V}$ & - \\
\hline
\end{tabular}

detected were $\mathrm{C}_{16: 1} \omega 11 c(8 \cdot 1 \%)$, iso- $\mathrm{C}_{15: 0}(7 \cdot 1 \%)$, anteiso- $\mathrm{C}_{17: 0}(4 \cdot 9 \%)$, iso- $\mathrm{C}_{16: 0}(4 \cdot 7 \%)$, iso- $\mathrm{C}_{17: 0}(4 \cdot 5 \%)$, $\mathrm{C}_{14: 0}(3 \cdot 9 \%)$ and iso- $\mathrm{C}_{14: 0}(2 \cdot 3 \%)$.

Phenotypic characterization was performed according to the standard methods described by Claus \& Berkeley (1986) and Logan \& Berkeley (1984) using strains P. illinoisensis DSM $11733^{\mathrm{T}}$ and $P$. pabuli DSM $3036^{\mathrm{T}}$ as references. The API 20E and API 20NE systems were also used to characterize the isolate according to the manufacturer's instructions (bioMérieux). Table 1 lists the phenotypic properties of strain XIL14 ${ }^{\mathrm{T}}$ as well as those of closely related Paenibacillus species. Strain XIL14 ${ }^{\mathrm{T}}$ differs from $P$. illinoisensis in terms of acetoin production, final $\mathrm{pH}$ in Voges-Proskauer medium, caseinase, growth at $\mathrm{pH} 5.6$ and growth at $50{ }^{\circ} \mathrm{C}$. It is differs with respect to $P$. pabuli in terms of optimum growth temperature, acetoin production and growth at $\mathrm{pH} 5 \cdot 6$.

Therefore, on the basis of the polyphasic taxonomic data we propose that isolate XIL14 ${ }^{\mathrm{T}}$ should be classified as representing a novel Paenibacillus species, for which the name Paenibacillus xylanilyticus sp. nov. is proposed.

\section{Description of Paenibacillus xylanilyticus sp. nov.}

Paenibacillus xylanilyticus (xy.la.ni.ly'ti.cus. N.L. n. xylanum xylan; Gr. adj. lytikos able to loosen; N.L. adj. lyticus - $a-u m$ dissolving; N.L. masc. adj. xylanilyticus xylan-dissolving).

Cells are rod-shaped, measuring 3.9-4 × 1.5-1.55 $\mu \mathrm{m}$ and motile by means of peritrichous flagella. Oval subterminal 
Table 2. Percentage of total cellular fatty acids from strain $\mathrm{XIL} 14^{\top}$ and phylogenetically related species of the genus Paenibacillus

Species: 1, P. xylanilyticus sp. nov. XIL14 ${ }^{\mathrm{T}} ; 2$, P. illinoisensis (data from Shida et al., 1997b); 3, P. pabuli (Shida et al., 1997a); 4, P. amylolyticus (Shida et al., 1997b). ND, Not detected.

\begin{tabular}{|c|c|c|c|c|}
\hline Fatty acid & 1 & 2 & 3 & 4 \\
\hline $\mathrm{C}_{14: 0}$ & $3 \cdot 9$ & $2 \cdot 0$ & $0 \cdot 7$ & $2 \cdot 9$ \\
\hline $\mathrm{C}_{15: 0}$ & ND & $1 \cdot 0$ & $0 \cdot 1$ & $0 \cdot 5$ \\
\hline $\mathrm{C}_{16: 0}$ & $16 \cdot 6$ & $24 \cdot 7$ & $10 \cdot 1$ & $12 \cdot 8$ \\
\hline iso- $\mathrm{C}_{14: 0}$ & $2 \cdot 3$ & $1 \cdot 8$ & $0 \cdot 7$ & $2 \cdot 3$ \\
\hline iso- $\mathrm{C}_{15: 0}$ & $7 \cdot 1$ & $1 \cdot 5$ & $2 \cdot 2$ & $2 \cdot 0$ \\
\hline iso- $\mathrm{C}_{16: 0}$ & $4 \cdot 7$ & $6 \cdot 3$ & $4 \cdot 8$ & $9 \cdot 0$ \\
\hline iso- $\mathrm{C}_{17: 0}$ & $4 \cdot 5$ & $1 \cdot 4$ & $1 \cdot 3$ & $3 \cdot 5$ \\
\hline anteiso- $\mathrm{C}_{15: 0}$ & $47 \cdot 9$ & $56 \cdot 6$ & $73 \cdot 7$ & $46 \cdot 2$ \\
\hline anteiso- $\mathrm{C}_{17: 0}$ & $4 \cdot 9$ & $4 \cdot 9$ & $4 \cdot 1$ & $2 \cdot 2$ \\
\hline $\mathrm{C}_{16: 1} \omega 11$ & $8 \cdot 1$ & $\mathrm{ND}$ & $\mathrm{ND}$ & $0 \cdot 1$ \\
\hline
\end{tabular}

spores are formed that slightly swell the sporangia. Colonies grown $\left(48 \mathrm{~h}, 37^{\circ} \mathrm{C}\right)$ on YNBX agar are circular, convex, cream-coloured, opaque and usually $1-3 \mathrm{~mm}$ in diameter. Cells are facultatively anaerobic and stain Gram-positive. Optimum growth temperature is $37^{\circ} \mathrm{C}$ and optimum $\mathrm{pH}$ is 7. Oxidase-negative and catalase-positive. The DNA $\mathrm{G}+\mathrm{C}$ content of the type strain is $50.5 \mathrm{~mol} \%$. The predominant fatty acids are anteiso- $\mathrm{C}_{15: 0}$ and $\mathrm{C}_{16: 0}$. Does not produce gas from glucose. Acid is produced from D-glucose, L-arabinose, $\mathrm{N}$-acetylglucosamine, sucrose, D-mannose, rhamnose, melibiose, maltose, xylose and mannitol. Able to use xylan as a carbon source. Unable to use inositol, sorbitol, citrate, propionate, caprate, adipate, malate or phenylacetate as sole sources of carbon. Produces xylanases, gelatinase, amylase and $\beta$-galactosidase but not urease, caseinase, phenylalanine deaminase, lysine decarboxylase, arginine dehydrolase, ornithine decarboxylase, tryptophan deaminase, tyrosinase, indole, dihydroxyacetone, hydrogen sulphide or acetoin (Voges-Proskauer medium). Nitrate reduction to nitrite is positive.

The type strain, XIL14 ${ }^{\mathrm{T}}\left(=\mathrm{LMG} 21957^{\mathrm{T}}=\right.$ CECT $\left.5839^{\mathrm{T}}\right)$, was isolated from air in a research laboratory from Salamanca University, Spain.

\section{Acknowledgements}

This work was supported by Spanish Government Grants to E. M.-M. and E. V. We are grateful to Professor Dr R. M. Kroppenstedt and Dr P. Schumann (DSMZ, Braunschweig, Germany) for their help with analysis of fatty acid methyl esters and DNA-DNA hybridization, respectively.

\section{References}

Ash, C., Priest, F. G. \& Collins, M. D. (1993). Molecular identification of rRNA group 3 bacilli (Ash, Farrow, Wallbanks and Collins) using a PCR probe test. Antonie van Leeuwenhoek 64, 253-260.
Ash, C., Priest, F. G. \& Collins, M. D. (1994). Paenibacillus gen. nov. In Validation of the Publication of New Names and New Combinations Previously Effectively Published Outside the IJSB. List no. 51. Int J Syst Bacteriol 44, 852-853.

Ay, J., Goetz, F., Borriss, R. \& Heinemann, U. (1998). Structure and function of the Bacillus hybrid enzyme GluXyn-1: native-like jellyroll fold preserved after insertion of autonomous globular domain. Proc Natl Acad Sci U S A 95, 6613-6618.

Cashion, P., Holder-Franklin, M. A., McCully, J. \& Franklin, M. (1977). A rapid method for the base ratio determination of bacterial DNA. Anal Biochem 81, 461-466.

Chun, J. \& Goodfellow, M. (1995). A phylogenetic analysis of the genus Nocardia with 16S rRNA sequences. Int J Syst Bacteriol 45, 240-245.

Claus, D. \& Berkeley, R. C. W. (1986). Genus Bacillus Cohn 1872, $174^{\mathrm{AL}}$. In Bergey's Manual of Systematic Bacteriology, pp. 1105-1138. Edited by P. H. A. Sneath, N. S. Mair, M. E. Sharpe \& J. G. Holt. Baltimore: Williams \& Wilkins.

De Ley, J., Cattoir, H. \& Reynaerts, A. (1970). The quantitative measurement of DNA hybridization from renaturation rates. Eur $J$ Biochem 12, 133-142.

Doetsch, R. N. (1981). Determinative methods of light microscopy. In Manual of Methods for General Bacteriology, pp. 21-33. Edited by P. Gerhardt, R. G. E. Murray, R. N. Costilow, E. W. Nester, W. A. Wood, N. R. Krieg \& G. B. Phillips. Washington, DC: American Society for Microbiology.

Escara, J. F. \& Hutton, J. R. (1980). Thermal stability and renaturation of DNA in dimethyl sulfoxide solutions: acceleration of the renaturation rate. Biopolymers 19, 1315-1327.

Hespell, R. B. (1996). Fermentation of xylan, corn fiber, or sugars to acetoin and butanediol by Bacillus polymyxa strains. Curr Microbiol 32, 291-296.

Huß, V. A. R., Festl, H. \& Schleifer, K. H. (1983). Studies on the spectrometric determination of DNA hybridization from renaturation rates. Syst Appl Microbiol 4, 184-192.

Jahnke, K. D. (1992). Basic computer program for evaluation of spectroscopic renaturation data from GILFORD System 2600 spectrometer on a PC/XT/AT type personal computer. J Microbiol Methods 15, 61-73.

Kimura, M. (1980). A simple method for estimating evolutionary rates of base substitutions through comparative studies of nucleotide sequences. J Mol Evol 16, 111-120.

Kumar, S., Tamura, K., Jakobsen, I. B. \& Nei, M. (2001). Molecular Evolutionary Genetics Analysis software. Tempe, AZ: Arizona State University.

Lee, H. J., Shin, D. J., Cho, N. C., Kim, H. O., Shin, S. Y., Im, S. Y., Lee, H. B., Chum, S. B. \& Bai, S. (2000). Cloning, expression and nucleotide sequences of two xylanase genes from Paenibacillus sp. Biotechnol Lett 22, 387-392.

Logan, N. A. \& Berkeley, R. C. W. (1984). Identification of Bacillus strains using the API system. J Gen Microbiol 130, 1871-1882.

Mandel, M. \& Marmur, J. (1968). Use of ultraviolet absorbance temperature profile for determining the guanine plus cytosine content of DNA. Methods Enzymol 12B, 195-206.

Meehan, C., Bjourson, A. J. \& McMullan, G. (2001). Paenibacillus azoreducens sp. nov., a synthetic azo dye decolorizing bacterium from industrial wastewater. Int J Syst Evol Microbiol 51, 1681-1685.

Morales, P., Madarro, A., Flors, A., Sendra, J. M. \& Pérez-González, J. A. (1995). Purification and characterization of a xylanase and an arabinofuranosidase from Bacillus polymyxa. Enzyme Microb Technol 17, 424-429. 
Nielsen, P. \& Sorensen, J. (1997). Multi-target and mediumindependent fungal antagonisms by hydrolytic enzymes in Paenibacillus polymyxa and Bacillus pumilus strains from barley rhizosphere. FEMS Microbiol Ecol 22, 183-192.

Pearson, W. R. \& Lipman, D. J. (1988). Improved tools for biological sequence comparison. Proc Natl Acad Sci U S A 85, 2444-2448.

Rivas, R., Sánchez, M., Trujillo, M. E., Zurdo-Piñeiro, J. L., Mateos, P. F., Martínez-Molina, E. \& Velázquez, E. (2003a). Xylanimonas cellulosilytica gen. nov., sp. nov., a xylanolytic bacterium isolated from a decayed tree (Ulmus nigra). Int J Syst Evol Microbiol 53, 99-103.

Rivas, R., Willems, A., Subba-Rao, N. S., Mateos, P. F., Kroppenstedt, R., Martínez-Molina, E., Gillis, M. \& Velázquez, E. (2003b). Description of Devosia neptuniae sp. nov. that nodulates and fixes nitrogen in symbiosis with Neptunia natans, an aquatic legume from India. Syst Appl Microbiol 26, 47-54.

Saitou, N. \& Nei, M. (1987). The neighbor-joining method: a new method for reconstructing phylogenetic trees. Mol Biol Evol 4, 406-425.

Shida, O., Takagi, H., Kadowaki, K., Nakamura, L.K. \& Komagata, K. (1997a). Transfer of Bacillus alginolyticus, Bacillus chondroitinus,
Bacillus curdlanolyticus, Bacillus glucanolyticus, Bacillus kobensis, and Bacillus thiaminolyticus to the genus Paenibacillus and emended description of the genus. Int J Syst Bacteriol 47, 289-298.

Shida, O., Takagi, H., Kadowaki, K., Nakamura, L. K. \& Komagata, K. (1997b). Emended description of Paenibacillus amylolyticus and description of Paenibacillus illinoisensis sp. nov. and Paenibacillus chibensis. Int J Syst Bacteriol 47, 299-306.

Thompson, J. D., Gibson, T. J., Plewniak, F., Jeanmougin, F. \& Higgins, D. G. (1997). The CLUSTAL_X windows interface: flexible strategies for multiple sequence alignment aided by quality analysis tools. Nucleic Acid Res 24, 4876-4882.

Velázquez, E., de Miguel, T., Poza, M., Rivas, R., Rosselló-Mora, R. \& Villa, T. G. (2004). Paenibacillus favisporus sp. nov., a xylanolytic bacterium isolated from cow faeces. Int J Syst Evol Microbiol 54, 59-64.

Wayne, L. G., Brenner, D. J., Colwell, R. R. \& 9 other authors (1987). Report of the ad hoc committee on reconciliation of approaches to bacterial systematics. Int J Syst Bacteriol 37, 463-464.

Zamost, B. L., Nielsen, H. K. \& Starnes, R. L. (1991). Thermostable enzymes for industrial applications. J Ind Microbiol 8, 71-82. 